\title{
Isolation and Structural Characterization of Lignin from Cardoon (Cynara cardunculus L.) Stalks
}

\author{
Ana Lourenço $^{1}$ (D) Jorge Rencoret $^{2} \cdot$ Catarina Chemetova $^{1} \cdot$ Jorge Gominho $^{1}$. \\ Ana Gutiérrez $^{2}$ - Helena Pereira ${ }^{1}$ - José C. del Río ${ }^{2}$
}

Published online: 9 July 2015

(C) Springer Science+Business Media New York 2015

\begin{abstract}
The lignin from Cynara cardunculus stalks was isolated by the classical Björkman method and characterized by pyrolysis coupled with gas chromatography and mass spectrometry (Py-GC/MS), two-dimensional nuclear magnetic resonance spectroscopy (2D-NMR), and derivatization followed by reductive cleavage (DFRC). The milled Cynara lignin (MCyL) was constituted mainly by guaiacyl (G) and syringyl-units(S) (S/G molar ratio of 0.7$)$, with the complete absence of $p$-hydroxyphenyl $(\mathrm{H})$ units. The 2D-NMR analysis indicated a predominance of alkyl-aryl ether linkages ( $70 \%$ of all inter unit linkages are $\left.\beta-O-4^{\prime}\right)$ and significant amounts of condensed structures such as phenylcoumarans $\left(\beta-5^{\prime}, 14 \%\right)$, resinols $\left(\beta-\beta^{\prime}, 7 \%\right)$, spirodienones $\left(\beta-1^{\prime}, 5 \%\right)$, and dibenzodioxocins $\left(5-5^{\prime}, 4 \%\right)$. Furthermore, the analyses indicated that the lignin is partially acylated at the $\gamma-\mathrm{OH}(12 \%$ acylation) by acetate groups and that acetylation occurs preferentially on syringyl-units. As in other plants, acetylation occurs at the monomer stage, and sinapyl acetate behaves as a real lignin monomer participating in lignification in cardoon stalks. The detailed structural characterization of cardoon lignin reported here will foster the industrial use of this biomass for the production of biofuels and other bio-based chemicals under the lignocellulosic biorefinery.
\end{abstract}

Ana Lourenço and Jorge Rencoret contributed equally to this work.

Ana Lourenço

analourenco@isa.ulisboa.pt

1 Centro de Estudos Florestais, Instituto Superior de Agronomia, Universidade de Lisboa, Tapada da Ajuda,

1349-017 Lisboa, Portugal

2 Instituto de Recursos Naturales y Agrobiología de Sevilla (IRNAS), CSIC, Reina Mercedes 10, PO Box 1052, E-41080 Seville, Spain
Keywords Cynara cardunculus $\cdot$ Milled Cynaralignin $(\mathrm{MCyL}) \cdot \mathrm{Py}-\mathrm{GC} / \mathrm{MS} \cdot 2 \mathrm{D}-\mathrm{NMR} \cdot \mathrm{DFRC} \cdot \mathrm{S} / \mathrm{G}$ ratio

\section{Introduction}

Cardoon (Cynara cardunculus L.) is an herbaceous perennial crop from the Asteraceae family with high biomass productivity under the Mediterranean conditions [1-3].Cardoon has several industrial applications, the stalks can be used for energy and pulp and paper production, oil can be extracted from the seeds to produce biodiesel, polyphenols with pharmacological properties can be extracted from the leaves, andcardosins (milk protease) from the capitula are traditionally used for cheese production [1].

The cardoon stalks have already been chemically characterized and comprised 5 to $11 \%$ ash, 13 to $21 \%$ extractives, 13 to $23 \%$ total lignin, and around $53 \%$ polysaccharides [4-7]. Lignin is the second major component of the cell wall matrix in cardoon in amounts similar to what occurs in other herbaceous plants, such as wheat straw, corn, switch grass, or Miscanthus, where it can represent from 18 to $25 \%$ [8].The lignin provides mechanical support for the plant, waterproofs the cell wall, enables the transport of water and nutrients, and provides a barrier against microorganisms. Some attempts have been made to isolate the lignin from woody and nonwoody plants since it is a good raw material for the production of diverse useful products, e.g., phenol-formaldehyde resins [9] and bio-oils [10]. However, its use is still experimental or residual, mainly due to the difficulties for finding efficient, environmental, and economically viable solutions for its isolation from the lignocellulosic matrix [11]. For an appropriate valorization of cardoon as a raw material for the production of added-value products, the comprehensive characterization of their different components is of high interest, in particular 
the composition and the structure of the lignin polymer, since it is a potential source of aromatic chemicals andbiofuels, as already mentioned.

However, studies regarding the detailed structure of the lignin of cardoon stalks are still scarce. Recently, a study was made to characterize the lignin in cardoon stalks by pyrolysis coupled with gas chromatography and mass spectrometry (Py-GC/MS), after fractionation in depithed stalks and pith [7]. The depithed stalks presented more lignin than pith (23.9 vs $21.8 \%)$ and a syringyl to guaiacyl $(\mathrm{S} / \mathrm{G})$ ratio of 1.3 and 2.1 , respectively. These previous studies were performed on cardoon stalks, and no efforts have been made so far to isolate its lignin for a detailed characterization or to evaluate its potential applications. To overcome this issue, in this paper, we report an exhaustive structural characterization of the lignin from cardoon stalks. For this purpose, we isolated the milled Cynara lignin $(\mathrm{MCyL})$ according to the classical isolation protocol [12], which was subsequently analyzed by different analytical methodologies, including Py-GC/MS, twodimensional nuclear magnetic resonance spectroscopy (2D-NMR), and derivatization followed by reductive cleavage (DFRC). Py-GC/MS is a reproducible and sensitive technique for the characterization of the composition of the lignin polymer, in terms of their $p$ hydroxyphenyl $(\mathrm{H})$, guaiacyl $(\mathrm{G})$, and syringyl (S) units [13-15]. 2D-NMR complements the information obtained by pyrolysis and provides useful information regarding the lignin units and lignin interunit linkages [16, 17]. Finally, DFRC is a chemical degradative method that can give information on the occurrence of acylated $\gamma-\mathrm{OH}$ units. Altogether, these data will provide a detailed picture of the structure of cardoon lignin that will help to maximize the industrial exploitation of this plant as potential feedstock for the production of bio-based materials.

\section{Material and Methods}

\section{Samples}

Cardoon samples were collected in the final stage of their growth cycle, in an experimental field of Instituto Superior de Agronomia in Lisbon, Portugal. The stalks were separated from the leaves, cut in small pieces, and dried in an oven at $60{ }^{\circ} \mathrm{C}$. The samples were milled in a knife mill (Retsch SM 2000), passing through a sieve of $6 \mathrm{~mm} \times 6 \mathrm{~mm}$, and successively extracted with dichloromethane, ethanol, and water for $24 \mathrm{~h}$ each. The extracted samples were dried in an oven at $60{ }^{\circ} \mathrm{C}$, milled in a knife mill (IKA MF10) passing through a 100 -mesh sieve to obtain sawdust.

\section{Chemical Analysis}

Two samples were collected for the chemical characterization, and the following parameters were determined: ash content (TAPPI T211 om-02); total extractives determined from successive extraction in a Soxhlet apparatus with dichloromethane, ethanol, and water (TAPPI T204 cm-07); total lignin determined in the extracted material as the sum of Klason lignin (TAPPI T222 om-11); and acid-soluble lignin (UM 205 om83). The neutral monosaccharide composition was determined in the hydrolysate from the lignin analysis and separated in an Aminotrap plus Carbopac SA10 column connected in a Dionex ICS-3000 High Pressure Ion Chromatography. The monosaccharides were reported as percentage of total monosaccharides.

\section{Lignin Isolation}

The milled Cynara lignin (MCyL) was prepared according to the classical procedure [12]. The sawdust was finely ballmilled in a Retsch PM100 planetarium ball mill at $400 \mathrm{rpm}$ using a $500-\mathrm{mL}$ agate jar and agate ball bearings $(20 \times 20 \mathrm{~mm})$. The total ball-milling time for the samples was $5 \mathrm{~h}$, with $5 \mathrm{~min}$ breaks after every $5 \mathrm{~min}$ of milling. The ball-milled powder $(60.34 \mathrm{~g})$ was extracted with dioxane-water $(96: 4, v / v)$ using $25 \mathrm{~mL}$ of solvent/g of milled sample, for $12 \mathrm{~h}$ under agitation. This solution was centrifuged, and the supernatant was evaporated to dryness at $40{ }^{\circ} \mathrm{C}$ at reduced pressure. The obtained residue, called raw MCyL $(0.79 \mathrm{~g})$, was dissolved into a solution of acetic acid/water $(9: 1, v / v)$ using $20 \mathrm{~mL}$ of solvent/g of raw MCyL. The lignin from the solution was precipitated into stirred cold water $(225 \mathrm{~mL} / \mathrm{g}$ of raw MCyL), and the formed precipitate was separated by centrifugation and milled in an agate mortar. This residue was dissolved in a solution of 1,2-dichcloroethane/ethanol solution (2:1, v/v) using $25 \mathrm{~mL}$ of this solution/g of lignin. After centrifugation to remove undissolved matter, the lignin in the supernatant was precipitated by adding the solution dropwise into diethyl ether, and the obtained residue was separated by centrifugation. The solid residue was suspended in diethyl ether overnight, centrifuged, and finally resuspended in petroleum ether overnight. The final purified MCyL sample was recovered by centrifugation and dried under $\mathrm{N}_{2}$ current. The yield of the isolated MCyL preparation was approximately $10 \%$ of the Klason lignin content.

\section{Analytical Pyrolysis (Py-GC/MS)}

The isolated MCyL $(1.7 \mathrm{mg})$ sample was pyrolyzed in a EGA/ Py-3030D microfurnace (Frontier Laboratories Ldt., Fukushima, Japan), connected to an Agilent 7820A GC system (Agilent Technologies, Inc., Santa Clara, CA) equipped with a DB-1701 fused silica capillary column $(60 \mathrm{~m} \times 0.25 \mathrm{~mm}$ 
Table 1 Chemical characterization of the whole stalks of Cynara cardunculus $\mathrm{L}$.

\begin{tabular}{ll}
\hline & $\%$ o.d. mass \\
\hline Ash & 5.0 \\
Total extractives & 8.9 \\
Dichloromethane & 0.7 \\
Ethanol & 3.9 \\
Water & 4.3 \\
Total lignin & 19.2 \\
Soluble lignin & 2.1 \\
Klason lignin & 17.1 \\
Monosaccharides $(\%$ of total neutral & \\
$\quad$ monosaccharides) & \\
Arabinose & 0.8 \\
Xylose & 30.9 \\
Mannose & 1.2 \\
Galactose & 1.3 \\
Glucose & 65.8 \\
\hline
\end{tabular}

i.d. $\times 0.25 \mu \mathrm{m}$ film thickness) and to a Agilent 5975 Mass detector (EI at $70 \mathrm{eV}$ ). The pyrolysis was performed at $500{ }^{\circ} \mathrm{C}$ during $1 \mathrm{~min}$, and the interface was kept at $280{ }^{\circ} \mathrm{C}$. The injector was at $250{ }^{\circ} \mathrm{C}$, the oven temperature was programmed to start at $45^{\circ} \mathrm{C}(4 \mathrm{~min})$, increasing the temperature to $280{ }^{\circ} \mathrm{C}$ at a heating rate of $4{ }^{\circ} \mathrm{C} / \mathrm{min}$, and was maintained at $280^{\circ} \mathrm{C}$ during $10 \mathrm{~min}$. The carrier gas was helium with a flow of $2 \mathrm{~mL} \mathrm{~min}^{-1}$. The compounds were identified by comparison of their mass spectra with those of the Wiley and NIST libraries and with those reported in the literature $[18,19]$ and, when possible, by comparison with the retention times and mass spectra of authentic standards. The peak molar areas of each compound were calculated, the summed areas were normalized and express as percentage.The response factors for most of the lignin-derived phenols released were practically identical, except for vanillin [20], which is a minor peak here. Therefore, no attempt was made to calculate the response factor for every single compound released.
Table 2 Identities and relative molar abundances ( $\%$ of identified) of the lignin-derived compounds identified in the Py-GC/MS of the MCyL lignin preparation isolated from Cynara cardunculus $\mathrm{L}$.

\begin{tabular}{|c|c|c|c|c|}
\hline Peak & Compound & Mw & Origin & Relative abundance $\%$ \\
\hline 1 & guaiacol & 124 & G & 10.0 \\
\hline 2 & 4-methylguaiacol & 138 & G & 9.2 \\
\hline 3 & 4-ethylguaiacol & 152 & G & 2.3 \\
\hline 4 & 4-vinylguaiacol & 150 & G & 6.5 \\
\hline 5 & eugenol & 164 & G & 1.5 \\
\hline 6 & 4-propylguiacol & 166 & G & 0.9 \\
\hline 7 & syringol & 154 & $\mathrm{~S}$ & 10.2 \\
\hline 8 & cis-isoeugenol & 164 & G & 2.0 \\
\hline 9 & trans-isoeugenol & 164 & G & 6.8 \\
\hline 10 & 4-methylsyringol & 168 & $\mathrm{~S}$ & 7.6 \\
\hline 11 & vanillin & 152 & G & 6.0 \\
\hline 12 & 4-propinylguaiacol & 162 & G & 0.5 \\
\hline 13 & 4-propinylguaiacol & 162 & G & 0.5 \\
\hline 14 & 4-ethylsyringol & 182 & G & 1.4 \\
\hline 15 & homovanillin & 166 & G & 1.2 \\
\hline 16 & vanillic acid methyl ester & 182 & G & 0.7 \\
\hline 17 & acetovanillone & 166 & G & 3.1 \\
\hline 18 & 4-vinylsyringol & 180 & $\mathrm{~S}$ & 4.0 \\
\hline 19 & 4-propylsyringol & 196 & $\mathrm{~S}$ & 0.4 \\
\hline 20 & guaiacylacetone & 180 & G & 0.6 \\
\hline 21 & 4-allylsyringol & 194 & $\mathrm{~S}$ & 1.2 \\
\hline 22 & cis-4-propenylsyringol & 194 & $\mathrm{~S}$ & 1.9 \\
\hline 23 & 4-propinylsyringol & 192 & $\mathrm{~S}$ & 0.3 \\
\hline 24 & 4-propinylsyringol & 192 & $\mathrm{~S}$ & 0.2 \\
\hline 25 & trans-4-propenylsyringol & 194 & $\mathrm{~S}$ & 4.9 \\
\hline 26 & syringaldehyde & 182 & $\mathrm{~S}$ & 4.9 \\
\hline 27 & homosyringaldehyde & 196 & $\mathrm{~S}$ & 0.8 \\
\hline 28 & syringic acid methyl ester & 212 & $\mathrm{~S}$ & 0.6 \\
\hline 29 & acetosyringone & 196 & $\mathrm{~S}$ & 2.3 \\
\hline 30 & syringylacetone & 210 & $\mathrm{~S}$ & 0.4 \\
\hline 31 & trans-coniferaldehyde & 178 & G & 4.2 \\
\hline 32 & propiosyringone & 210 & $\mathrm{~S}$ & 0.6 \\
\hline \multirow[t]{2}{*}{33} & trans-sinapaldehyde & 208 & $\mathrm{~S}$ & 2.4 \\
\hline & $\mathrm{S} / \mathrm{G}$ molar ratio & & & 0.79 \\
\hline
\end{tabular}

Fig. 1 Py-GC/MS

chromatogram of the lignin isolated from Cynara cardunculus $\mathrm{L}$. The identities and relative abundances of the released lignin-derived compounds are listed in Table 2

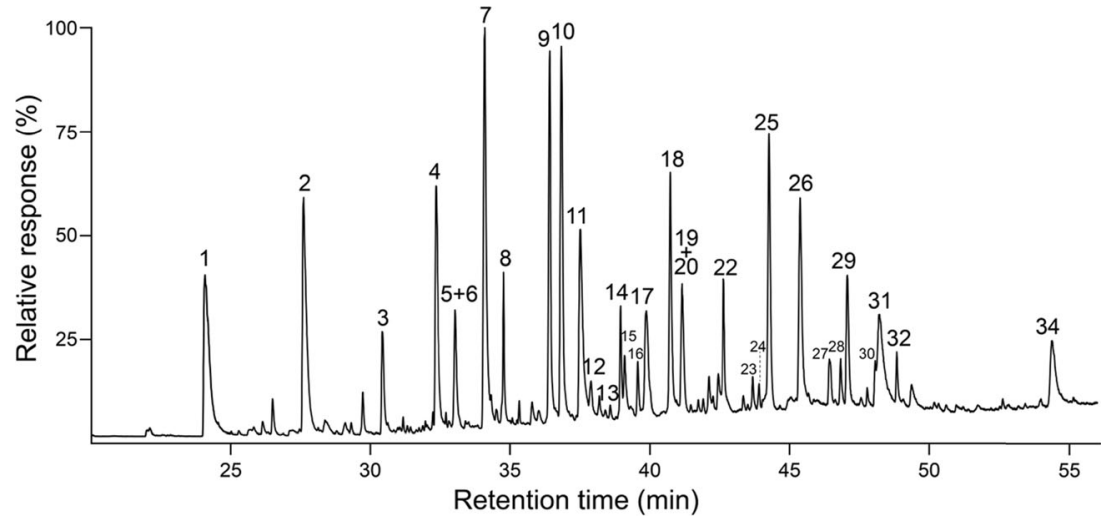




\section{D-NMR Spectroscopy}

Around $30 \mathrm{mg}$ of MCyL sample was dissolved in $0.75 \mathrm{~mL}$ of DMSO- $d_{6}$ for the NMR analysis. Heteronuclear single quantum correlation (HSQC) spectra were recorded at $300 \mathrm{~K}$ on a Bruker AVANCE III $500 \mathrm{MHz}$ spectrometer (Bruker Biospin, Fallanden, Switzerland), equipped with a cryogenically cooled $5 \mathrm{~mm}$ TCI gradient probe with inverse geometry (proton coils closest to the sample). The $2 \mathrm{D}{ }^{13} \mathrm{C}-{ }^{1} \mathrm{H}$ correlation spectra were obtained using an adiabatic HSQC pulse program (Bruker standard pulse sequence "hsqcetgpsisp2.2"). The spectral width was from 10 to $0 \mathrm{ppm}(5000 \mathrm{~Hz})$ in $\mathrm{F}_{2}$ for ${ }^{1} \mathrm{H}$ dimension, with an acquisition time of $145 \mathrm{~ms}$ and a recycle delay (d1) of $1 \mathrm{~s}$. For the ${ }^{13} \mathrm{C}$ dimension, the spectral width was from 200 to $0 \mathrm{ppm}(25,168 \mathrm{~Hz})$ in $\mathrm{F}_{1}$, being collected 256 increments of 32 scans for a total acquisition time of $2 \mathrm{~h} 40 \mathrm{~min}$. The ${ }^{1} J_{\mathrm{CH}}$ used was $145 \mathrm{~Hz}$. Processing used typical matched Gaussian apodization in ${ }^{1} \mathrm{H}$ and a squared cosine bell in ${ }^{13} \mathrm{C}$. The central solvent peak was used as an internal reference $\left(\delta_{\mathrm{C}} 39.5 ; \delta_{\mathrm{H}}\right.$ $2.49 \mathrm{ppm})$.

2D-NMR HSQC cross-signals were assigned after comparison with data from literature [17,21-25]. A semi-quantitative analysis of the volume integrals of the HSQC correlation peaks was performed using Bruker's Topspin 3.1 processing software. Integration of signals corresponding to chemically analogous $\mathrm{C}-\mathrm{H}$ with similar ${ }^{1} J_{\mathrm{CH}}$ coupling values was performed separately for the different regions of the spectra. In the aliphatic oxygenated region, the relative abundances of side-chains involved in the various interunit linkages were estimated from the $\mathrm{C}_{\alpha}-\mathrm{H}_{\alpha}$ correlations to avoid possible interference from homonuclear ${ }^{1} \mathrm{H}-{ }^{1} \mathrm{H}$ couplings, except for cinnamyl alcohol end-groups, for which $\mathrm{C}_{\gamma}-\mathrm{H}_{\gamma}$ correlations had to be used. In the aromatic/unsaturated region, $\mathrm{C}_{2}-\mathrm{H}_{2}$ correlations from $\mathrm{H}, \mathrm{G}$, and $\mathrm{S}$ lignin units were used to estimate their relative abundances.

\section{Derivatization Followed by Reductive Cleavage (DFRC)}

To assess the incorporation of naturally $\gamma$-acetylated monolignols into the cardoon lignin, resulting in $\gamma$ acetylated lignin side-chains, a modification of the standard DFRC method using propionylating instead of acetylating reagents (so-called DFRC') was used [26]. Lignin (5 mg) was stirred for $2 \mathrm{~h}$ at $50{ }^{\circ} \mathrm{C}$ with propionyl bromide in propionic acid $(8: 92, v / v)$. The solvents and excess bromide were removed by rotary evaporation. The products were then dissolved in dioxane/propionic acid/water $(5: 4: 1, v / v / v)$, and $50 \mathrm{mg}$ powdered $\mathrm{Zn}$ was added. After stirring for $40 \mathrm{~min}$ at room temperature, the mixture was transferred into a separatory funnel with dichloromethane and saturated ammonium chloride. The aqueous phase was adjusted to $\mathrm{pH}<3$ by adding $3 \% \mathrm{HCl}$, the mixture vigorously mixed, and the organic layer separated. The water phase was extracted twice more with dichloromethane. The combined dichloromethane fractions were dried over anhydrous $\mathrm{NaSO}_{4}$, and the filtrate was evaporated to dryness using a rotary evaporator. The residue was subsequently propionylated for $1 \mathrm{~h}$ in $1.1 \mathrm{~mL}$ of dichloromethane containing $0.2 \mathrm{~mL}$ of propionic anhydride and $0.2 \mathrm{~mL}$ pyridine. The propionylated (and naturally acetylated) lignin degradation compounds were collected after rotary evaporation of the solvents, and subsequently analyzed
Fig. 2 a Side-chain and $\mathbf{b}$ aromatic/unsaturated regions in the HSQC NMR spectra of the lignin isolated from Cynara cardunculus $\mathrm{L}$. The signal assignments are presented in Table 3, and the main lignin structures identified are depicted in Fig. 3
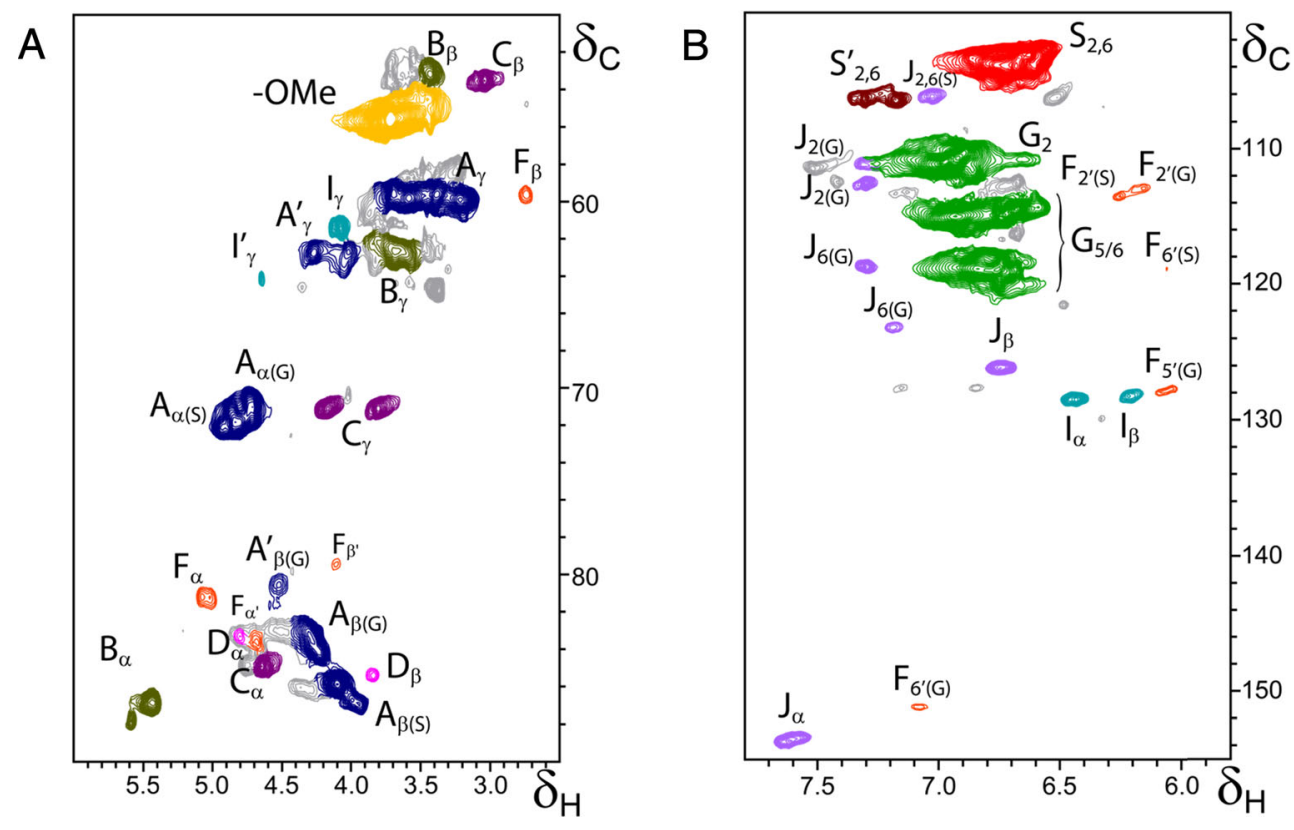
by GC/MS. The GC/MS analyses were performed with a GCMS-QP2010 Ultra instrument (Shimadzu Co.) using a capillary column (DB-5HT $30 \mathrm{~m} \times 0.25 \mathrm{~mm}$ I.D., $0.10 \mu \mathrm{m}$ film thickness). The oven was heated from $140{ }^{\circ} \mathrm{C}(1 \mathrm{~min})$ to $250{ }^{\circ} \mathrm{C}$ at $3{ }^{\circ} \mathrm{C} / \mathrm{min}$, then ramped at $10{ }^{\circ} \mathrm{C} / \mathrm{min}$ to $300{ }^{\circ} \mathrm{C}$, and held for $10 \mathrm{~min}$ at the final temperature. The injector was set at $250{ }^{\circ} \mathrm{C}$, and the transfer line was kept at $300{ }^{\circ} \mathrm{C}$. Helium was used as the carrier gas at a rate of $1 \mathrm{~mL} / \mathrm{min}$.

\section{Results and Discussion}

\section{Chemical Characterization of Cardoon Stalks}

The chemical characterization of the cardoon stalks is presented in Table 1 . The stalks presented a high ash content of $5 \%$; similar and even higher ash contents have been reported in cardoon stalks by several authors $[4,5]$. The extractives
Table 3 Assignments of the lignin ${ }^{13} \mathrm{C}-{ }^{1} \mathrm{H}$ correlation peaks in the 2D HSQC spectra of cardoon and the isolated $\mathrm{MCyL}$

\begin{tabular}{|c|c|c|}
\hline Label & $\delta_{\mathrm{C}} / \delta_{\mathrm{H}}$ & Assignment \\
\hline $\mathrm{B}_{\beta}$ & $53.1 / 3.43$ & $\mathrm{C}_{\beta}-\mathrm{H}_{\beta}$ in phenylcoumaran substructures (B) \\
\hline $\mathrm{C}_{\beta}$ & $53.5 / 3.05$ & $\mathrm{C}_{\beta}-\mathrm{H}_{\beta}$ in $\beta-\beta^{\prime}$ resinol substructures $(\mathbf{C})$ \\
\hline$-\mathrm{OCH}_{3}$ & $55.6 / 3.73$ & $\mathrm{C}-\mathrm{H}$ in methoxyls \\
\hline $\mathrm{A}_{\gamma}$ & $59.4 / 3.40$ and 3.72 & $\mathrm{C}_{\gamma}-\mathrm{H}_{\gamma}$ in $\beta-O-4^{\prime}$ substructures (A) \\
\hline $\mathrm{F}_{\beta}$ & $59.5 / 2.75$ & $\mathrm{C}_{\beta}-\mathrm{H}_{\beta}$ in spirodienone substructures $(\mathbf{F})$ \\
\hline $\mathrm{I}_{\gamma}$ & $61.3 / 4.08$ & $\mathrm{C}_{\gamma}-\mathrm{H}_{\gamma}$ in cinnamyl alcohol end-groups (I) \\
\hline $\mathrm{B}_{\gamma}$ & $62.6 / 3.67$ & $\mathrm{C}_{\gamma}-\mathrm{H}_{\gamma}$ in phenylcoumaran substructures $(\mathbf{B})$ \\
\hline $\mathrm{A}_{\gamma}^{\prime}$ & $63.5 / 3.83$ and 4.30 & $\mathrm{C}_{\gamma}-\mathrm{H}_{\gamma}$ in $\gamma$-acylated $\beta-O-4^{\prime}$ substructures $\left(\mathbf{A}^{\prime}\right)$ \\
\hline $\mathrm{I}_{\gamma}^{\prime}$ & $64.1 / 4.77$ & $\mathrm{C}_{\gamma}-\mathrm{H}_{\gamma}$ in $\gamma-p$-coumaroylated cinnamyl alcohol end-groups ( $\left.\mathbf{I}^{\prime}\right)$ \\
\hline $\mathrm{C}_{\gamma}$ & $71.0 / 3.83$ and 4.19 & $\mathrm{C}_{\gamma}-\mathrm{H}_{\gamma}$ in $\beta-\beta^{\prime}$ resinol substructures $(\mathbf{C})$ \\
\hline $\mathrm{A}_{\alpha} / \mathrm{A}_{\alpha}^{\prime}$ & $71.1 / 4.71$ & $\mathrm{C}_{\alpha}-\mathrm{H}_{\alpha}$ in $\beta-O-4^{\prime}$ substructures $\left(\mathbf{A}, \mathbf{A}^{\prime}\right)$ \\
\hline $\mathrm{F}_{\beta^{\prime}}$ & $79.4 / 4.10$ & $\mathrm{C}_{\beta}-\mathrm{H}_{\beta^{\prime}}$ in spirodienone substructures $(\mathbf{F})$ \\
\hline $\mathrm{A}_{\beta(\mathrm{G})}^{\prime}$ & $80.8 / 4.52$ & $\mathrm{C}_{\beta}-\mathrm{H}_{\beta}$ in $\gamma$-acylated $\beta-O-4^{\prime}$ substructures linked to a G-unit (A') \\
\hline $\mathrm{F}_{\alpha}$ & $81.2 / 5.01$ & $\mathrm{C}_{\alpha}-\mathrm{H}_{\alpha}$ in spirodienone substructures $(\mathbf{F})$ \\
\hline $\mathrm{D}_{\alpha}$ & $83.0 / 4.82$ & $\mathrm{C}_{\alpha}-\mathrm{H}_{\alpha}$ in 5-5' (dibenzodioxocin) substructures (D) \\
\hline $\mathrm{F}_{\alpha^{\prime}}$ & $83.6 / 4.68$ & $\mathrm{C}_{\alpha^{\prime}}-\mathrm{H}_{\alpha^{\prime}}$ in spirodienone substructures $(\mathbf{F})$ \\
\hline$A_{\beta(G)}$ & $83.7 / 4.26$ & $\mathrm{C}_{\beta}-\mathrm{H}_{\beta}$ in $\beta-O-4^{\prime}$ substructures (A) linked to a $\mathrm{G}$ unit \\
\hline $\mathrm{C}_{\alpha}$ & $84.7 / 4.64$ & $\mathrm{C}_{\alpha}-\mathrm{H}_{\alpha}$ in $\beta-\beta^{\prime}$ resinol substructures $(\mathbf{C})$ \\
\hline $\mathrm{D}_{\beta}$ & $85.2 / 3.85$ & $\mathrm{C}_{\beta}-\mathrm{H}_{\beta}$ in 5-5' (dibenzodioxocin) substructures (D) \\
\hline $\mathrm{A}_{\beta(\mathrm{S})}$ & $85.8 / 4.09$ & $\mathrm{C}_{\beta}-\mathrm{H}_{\beta}$ in $\beta-O-4^{\prime}$ substructures linked (A) to a $\mathrm{S}$ unit \\
\hline $\mathrm{B}_{\alpha}$ & $86.8 / 5.43$ & $\mathrm{C}_{\alpha}-\mathrm{H}_{\alpha}$ in phenylcoumaran substructures (B) \\
\hline $\mathrm{S}_{2,6}$ & $103.7 / 6.68$ & $\mathrm{C}_{2}-\mathrm{H}_{2}$ and $\mathrm{C}_{6}-\mathrm{H}_{6}$ in etherified syringyl units $(\mathbf{S})$ \\
\hline $\mathrm{J}_{2,6(\mathrm{~S})}$ & 106.2/7.02 & $\mathrm{C}_{2}-\mathrm{H}_{2}$ and $\mathrm{C}_{6}-\mathrm{H}_{6}$ in sinapaldehyde end-groups $(\mathbf{J})$ \\
\hline $\mathrm{S}_{2,6}^{\prime}$ & $106.3 / 7.32$ and 7.20 & $\mathrm{C}_{2}-\mathrm{H}_{2}$ and $\mathrm{C}_{6}-\mathrm{H}_{6}$ in $\mathrm{C}_{\alpha}$-oxidized syringyl units $\left(\mathbf{S}^{\prime}\right)$ \\
\hline $\mathrm{G}_{2}$ & $110.8 / 6.96$ & $\mathrm{C}_{2}-\mathrm{H}_{2}$ in guaiacyl units $(\mathbf{G})$ \\
\hline $\mathrm{J}_{2(\mathrm{G})}$ & $111.2 / 7.31$ & $\mathrm{C}_{2}-\mathrm{H}_{2}$ and $\mathrm{C}_{6}-\mathrm{H}_{6}$ in coniferaldehyde end-groups $(\mathbf{J})$ \\
\hline $\mathrm{J}_{2(\mathrm{G})}$ & $112.5 / 7.30$ & $\mathrm{C}_{2}-\mathrm{H}_{2}$ in coniferaldehyde end-groups $(\mathbf{J})$ \\
\hline $\mathrm{F}_{2^{\prime}(\mathrm{G})}$ & $113.0 / 6.17$ & $\mathrm{C}_{2}-\mathrm{H}_{2^{\prime}}$ in spirodienone substructures $(\mathbf{F})$ \\
\hline $\mathrm{F}_{2^{\prime}(\mathrm{S})}$ & $113.5 / 6.25$ & $\mathrm{C}_{2}-\mathrm{H}_{2^{\prime}}$ in spirodienone substructures $(\mathbf{F})$ \\
\hline $\mathrm{G}_{5} / \mathrm{G}_{6}$ & $115.0 / 6.74$ & $\mathrm{C}_{5}-\mathrm{H}_{5}$ and $\mathrm{C}_{6}-\mathrm{H}_{6}$ inguaiacyl units $(\mathbf{G})$ \\
\hline $\mathrm{G}_{5}$ & $118.7 / 6.77$ & $\mathrm{C}_{5}-\mathrm{H}_{5}$ inguaiacyl units $(\mathbf{G})$ \\
\hline $\mathrm{J}_{6(\mathrm{G})}$ & $118.8 / 7.30$ & $\mathrm{C}_{6}-\mathrm{H}_{6}$ in coniferaldehyde end-groups $(\mathbf{J})$ \\
\hline $\mathrm{F}_{6^{\prime}(\mathrm{S})}$ & $118.9 / 6.06$ & $\mathrm{C}_{6}-\mathrm{H}_{6^{\prime}}$ in spirodienone substructures $(\mathbf{F})$ \\
\hline $\mathrm{J}_{6(\mathrm{G})}$ & $123.2 / 7.19$ & $\mathrm{C}_{6}-\mathrm{H}_{6}$ in coniferaldehyde end-groups $(\mathbf{J})$ \\
\hline $\mathrm{J}_{\beta}$ & $126.3 / 6.76$ & $\mathrm{C}_{\beta}-\mathrm{H}_{\beta}$ in cinnamaldehyde end-groups $(\boldsymbol{J})$ \\
\hline $\mathrm{F}_{5^{\prime}(\mathrm{G})}$ & $127.9 / 6.06$ & $\mathrm{C}_{5},-\mathrm{H}_{5^{\prime}}$ in spirodienone substructures $(\mathbf{F})$ \\
\hline $\mathrm{I}_{\beta}$ & $128.4 / 6.23$ & $\mathrm{C}_{\beta}-\mathrm{H}_{\beta}$ in cinnamyl alcohol end-groups (I) \\
\hline $\mathrm{I}_{\alpha}$ & $128.4 / 6.44$ & $\mathrm{C}_{\alpha}-\mathrm{H}_{\alpha}$ in cinnamyl alcohol end-groups (I) \\
\hline $\mathrm{F}_{6^{\prime}(\mathrm{G})}$ & $151.2 / 7.07$ & $\mathrm{C}_{6}-\mathrm{H}_{6^{\prime}}$ in spirodienone substructures $(\mathbf{F})$ \\
\hline $\mathrm{J}_{\alpha}$ & $153.4 / 7.61$ & $\mathrm{C}_{\alpha}-\mathrm{H}_{\alpha}$ in cinnamaldehyde end-groups $(\boldsymbol{J})$ \\
\hline
\end{tabular}


accounted for $8.9 \%$, in the range of values already reported for this plant $[4-6,27]$. Nevertheless, this value is slightly higher than that reported for other herbaceous plants, such as Miscanthus $\times$ giganteus $(4.1 \%$ ) [28], but lower than the values reported for elephant grass (10.5 to $12.7 \%$ ) [22]. The high extractive content in cardoon stalks was mainly due to polar compounds $(3.9 \%$ of ethanol solubles and $4.3 \%$ of water solubles), while the lipophilic compounds represented only a minor fraction $(0.7 \%)$, near to the range (1 to $2 \%$ ) previously reported [29].

The total lignin content in cardoon stalks was $19.2 \%$, a value slightly higher than the $17.0 \%$ reported by Pereira et al. [5], or the $16.4 \%$ reported by Ballesteros et al. [27]. However, this lignin content is lower than in other herbaceous plants, such as Miscanthus $\times$ giganteus, with a lignin content of $21.7 \%$ [28], or elephant grass, with $20.5 \%$ of lignin content [22].

Table 1 also presents the monosaccharide composition, where glucose and xylose are the main compounds, representing 65.8 and $30.9 \%$ of total monosaccharides, as reported in the literature [5].

\section{Lignin Composition as Observed by Py-GC/MS}

The pyrogram of the isolated MCyL is presented in Fig. 1. The identities and relative molar abundances of the released compounds are listed in Table 2. Pyrolysis of MCyL released phenolic compounds derived from guaiacyl $(G)$ and syringyl (S) lignin units, whereas compounds derived from $p$ hydroxyphenyl $(\mathrm{H})$ lignin units were completely absent. The predominant lignin-derived phenolic compounds released were guaiacol (1), 4-methylguaiacol (2), 4-vinylguaiacol (4), syringol (7), trans-isoeugenol (9), 4-methylsyringol (10), vanillin (11), 4-vinylsyringol (18), trans-4-propenylsyringol (25), and syringaldehyde (26), among others. In general,a similar distribution of lignin-derived compounds was obtained by pyrolysis of whole cardoon stalks [7]. In the pyrogram of the
Fig. 3 Main structures present in the MCyL: a $\beta-O-4$ ' alkyl-aryl ethers. $\mathbf{a}^{\prime} \beta-O-4^{\prime}$ alkyl-aryl ethers with acylated $\gamma-\mathrm{OH}$; b phenylcoumarans; c resinols; d dibenzodioxocins; $\mathbf{f}$ spirodienones; i cinnamyl alcohol end-groups; $\mathbf{j}$ cinnamaldehyde end-groups; $\mathbf{g}$ guaiacyl units; $\mathbf{s}$ syringyl units; $\mathbf{s} \mathrm{C} \alpha$-oxidized syringyl units<smiles>CCOc1c(C)cc(C(O)C(CO)Oc2c(C)cc(CC)cc2OC)cc1OC</smiles>

A

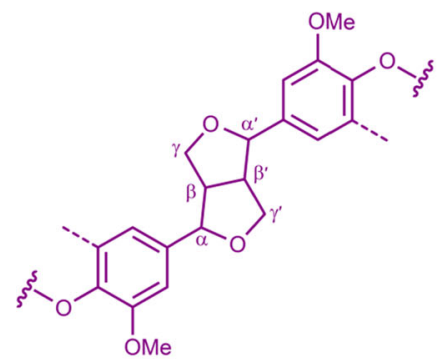

C<smiles>CCOc1c(C)cc(C(O)C(Oc2c(C)cc(C(C)C)cc2OC)[Te]OC(C)=O)cc1OC</smiles>

$A^{\prime}$

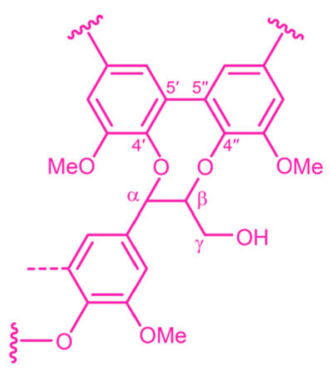

D<smiles>CCOc1c(C)cc(C2Oc3c(OC)cc(OC)cc3[C@@H](CO)C2COC)cc1OC</smiles>

B

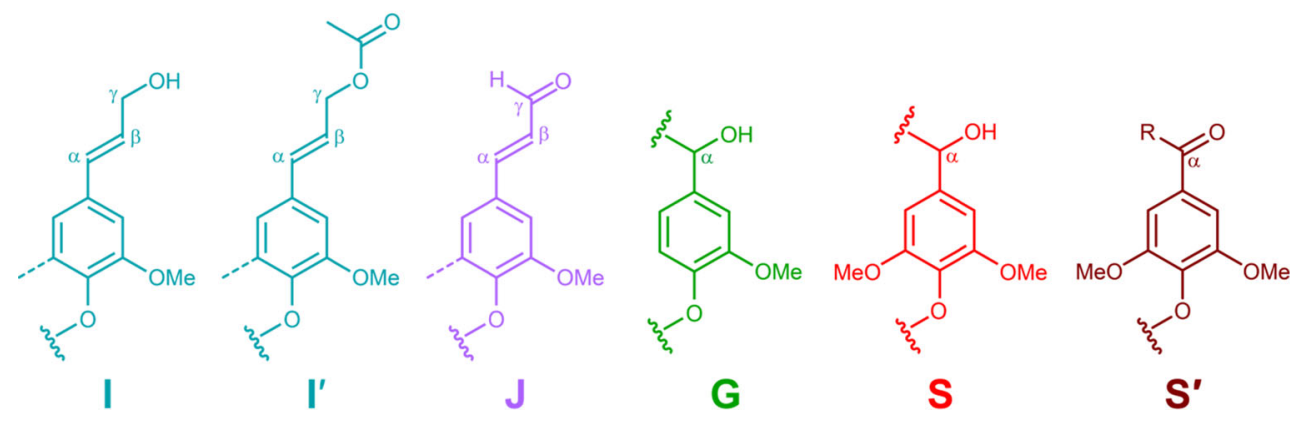


MCyL, the G-derived phenolic compounds were released in higher abundances than the respective S-lignin phenols, with a S/G molar ratio of 0.79 .

The enrichment in G-lignin observed in cardoon stalks would make this lignin slightly recalcitrant toward depolymerization. This may affect the delignification stages during alkaline pulping, due to the lower reactivity of the G-lignin compared to S-lignin in alkaline systems [30]. The $\mathrm{G}$ units have a free $\mathrm{C}-5$ position available for additional carbon-carbon or ether inter-unit bonds, which make them fairly resistant to lignin depolymerization during alkaline pulping. Therefore, lower $\mathrm{S} / \mathrm{G}$ ratios imply lower delignification rates, more alkali consumption, and therefore lower pulp yield $[14,31]$.

\section{Lignin Structural Units and Interunit Linkages as Seen by $2 D-N M R$}

2D-NMR is a powerful technique for the elucidation of lignin structure and has been extensively applied for the characterization of lignocellulosic materials [21-23, 32]. The oxygenated aliphatic side-chain $\left(\delta_{\mathrm{C}} / \delta_{\mathrm{H}} 50-90 / 2.5-6.0\right)$ and the aromatic $\left(\delta_{\mathrm{C}} / \delta_{\mathrm{H}} 100-156 / 5.8-7.8\right)$ regions of the HSQC spectrum of the isolated $\mathrm{MCyL}$ are presented in Fig. 2. The main lignin cross-signals are assigned in Table 3, while the main lignin structures are depicted in Fig. 3.

The side-chain region of the HSQC spectrum (Fig. 2a) provides information of the interunit linkages in lignin. In this region of the spectrum cross-signals from methoxyls $\left(\delta_{\mathrm{C}} / \delta_{\mathrm{H}} 55.6 /\right.$ 3.73) and from $\beta-O-4^{\prime}$ substructures (structure $\mathbf{A}$ ) are the most prominent. Interestingly, the HSQC spectrum clearly showed the presence of intense signals in the range from $\delta_{\mathrm{C}} / \delta_{\mathrm{H}} 63.5 /$ $3.83-4.30$ and at $64.1 / 4.77$ corresponding to the $\mathrm{C}_{\gamma}-\mathrm{H}_{\gamma}$ correlations of $\gamma$-acylated units (structures $\mathbf{A}^{\prime}$ and $\mathbf{I}^{\prime}$ ). The HSQC spectrum therefore indicates that this lignin is, at least partially, acylated at the $\gamma$-position of the lignin side-chain, as discussed below. Signals for condensed structures were also detected in the HSQC spectrum, although with lower intensities, including signals for phenylcoumarans (B), resinols (C), dibenzodioxocins (D), and spirodienones (F). Signals for cinnamyl alcohol endgroups (I) were also observed in this region of the spectrum.

The aromatic region of the spectra showed signals for Gand S-lignin units. The G-lignin units showed prominent signals for $\mathrm{C}_{2}-\mathrm{H}_{2}$ correlations at $\delta_{\mathrm{C}} / \delta_{\mathrm{H}} 110.8 / 6.96$ and for $\mathrm{C}_{5}-\mathrm{H}_{5}$ and $\mathrm{C}_{6}-\mathrm{H}_{6}$ correlations $\left(\delta_{\mathrm{C}} / \delta_{\mathrm{H}} 115.0 / 6.74\right.$ and 118.7/6.77). The S-lignin units showed a prominent signal corresponding to the $\mathrm{C}_{2,6}-\mathrm{H}_{2,6}$ correlations at a $\delta_{\mathrm{C}} / \delta_{\mathrm{H}} 103.7 / 6.68$ in etherified S-units $\left(\mathbf{S}_{2,6}\right)$. Signals corresponding to $\mathrm{C}_{2,6}-\mathrm{H}_{2,6}$ correlations in $C \alpha$-oxidized S-lignin units $\left(\mathbf{S}_{\mathbf{2 , 6}}^{\prime}\right)$ were observed at $\delta_{\mathrm{C}} / \delta_{\mathrm{H}}$ 106.3/7.32 and 7.20. Signals for H-lignin units were not observed in the HSQC spectrum, in agreement with the results obtained by Py-GC/MS. In this region of the HSQC spectrum, it was also possible to detect signals from cinnamyl alcohol end-groups (I) and cinnamaldehyde end-groups $(\mathbf{J})$. The total relative content of the cinnamaldehyde end-groups was estimated by comparison of the intensities of the $\mathrm{C}_{\beta}-\mathrm{H}_{\beta}$ correlations in cinnamyl alcohols $(\mathbf{I})$ and aldehydes $(\mathbf{J})$. In addition, signals for the aromatic units of the spirodienones $(\mathbf{F})$ are also observed in this region.

The relative abundances of the main inter-unit linkages (referred to as the total side-chains), cinnamyl end-groups, percentage of acylation of the lignin side-chain, as well as the relative abundances of the $\mathrm{H}-, \mathrm{G}-$, and $\mathrm{S}-\mathrm{units}_{\mathrm{t}}$ and the $\mathrm{S} / \mathrm{G}$ ratio in MCyL, calculated from volume integrations in the HSQC spectrum, are shown in Table 4. The results indicate that the main lignin substructure present in MCyL is the $\beta-O-4^{\prime}$ alkyl-aryl ether linkages (A), accounting for $70 \%$ of all sidechains, followed by important amounts of phenylcoumarans (14\%), resinols (7\%), dibenzodioxocins (4\%), and spirodienones (5\%). Cinnamyl end-groups (I, J) were present in relatively high abundances, and accounting each one for $6 \%$ of all inter-unit linkages. An estimation of the percentage of $\gamma$ acylation of the lignin side-chain in $\beta-O-4^{\prime}$ structures was performed by integration of the signals corresponding to the hydroxylated versus acylated $\mathrm{C}_{\gamma}-\mathrm{H}_{\gamma}$ correlations, and amounted to $12 \%$ of the lignin side-chains. The same $12 \%$ value was also obtained for $\gamma$-acylated cinnamyl alcohol endgroups (I') by integration of their signals. This is a rather low value when compared to those obtained in other plants such as sisal, elephant grass, or Miscanthus that presented, respectively, $68,39-55$, and $46 \%$ of acylation [22, 33, 34]. Lignin acylation

Table 4 Structural characteristics (lignin interunit linkages, endgroups, percentage of $\gamma$-acetylation, aromatic units, and $\mathrm{S} / \mathrm{G}$ ratio) from integration of ${ }^{13} \mathrm{C}-{ }^{1} \mathrm{H}$ correlation peaks in the HSQC spectrum of the isolated lignin $(\mathrm{MCyL})$ from Cynara cardunculus $\mathrm{L}$.

$\mathrm{MCyL}$

Lignin inter-unit linkages (\%)

$\beta-O-4^{\prime}$ aryl ethers $\left(\mathbf{A} / \mathbf{A}^{\prime}\right) \quad 70$

Phenylcoumarans (B) 14

Resinols (C)

Dibenzodioxocins (D) 4

Spirodienones $(\mathbf{F})$

Lignin end-groups ${ }^{a}$

Cinnamyl alcohol end-groups (I) 5

$\gamma$-acylated cinnamyl alcohol end-groups (I') 1

Cinnamaldehyde end-groups (J) 6

Lignin side-chain $\gamma$-acetylation (\%) 12

Lignin aromatic units ${ }^{b}$

$\mathrm{H}(\%) \quad 0$

$\mathrm{G}(\%) \quad 58$

$\mathrm{S}(\%) \quad 42$

$\mathrm{S} / \mathrm{G}$ ratio $\quad 0.7$

${ }^{a}$ Expressed as a fraction of the total lignin interunit linkage types $\mathbf{A}-\mathbf{F}$

${ }^{\mathrm{b}}$ Molar percentages $(\mathrm{H}+\mathrm{G}+\mathrm{S}=100)$ 
Fig. 4 Chromatogram (GC-TIC) of the DFRC' degradation products from the $\mathrm{MCyL}$ isolated from Cynara cardunculus L. c G, $t \mathrm{G}, c \mathrm{~S}$, and $t \mathrm{~S}$ are the normal cisand trans-coniferyl and sinapyl alcohol monomers (as their dipropionylated derivatives). $c \mathrm{Sac}$ and $t \mathrm{Sac}$ are the natively $\gamma$ acetylated cis- and trans-sinapyl alcohol (syringyl) monomers (as their phenolpropionylated derivatives)

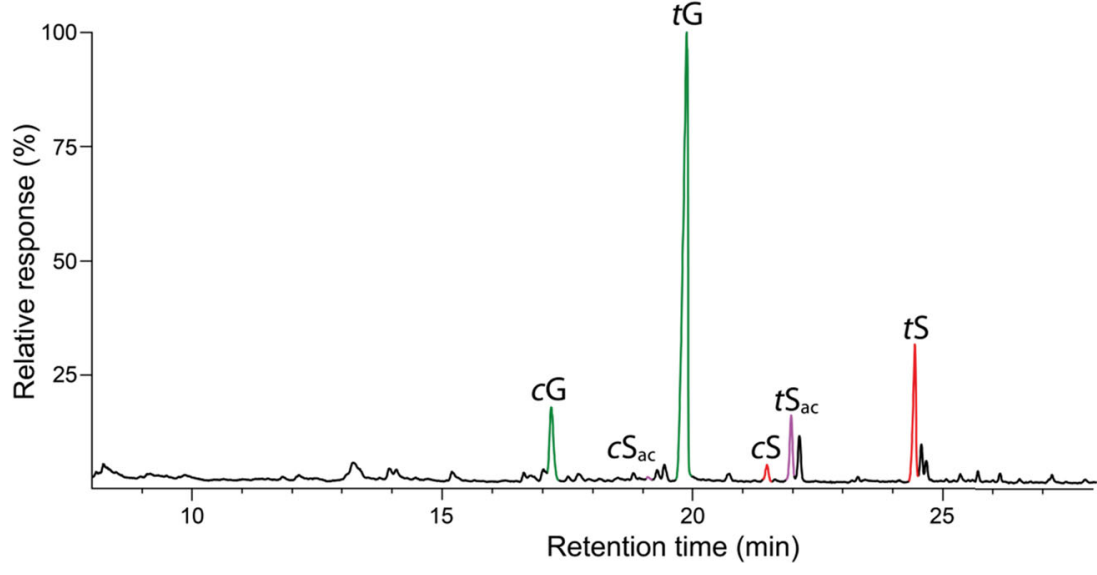

in cardoon stalks occurred exclusively at the $\mathrm{C} \gamma$ position, as also reported for other plants [35]. The S/G ratio estimated by NMR was 0.7 showing a slightly predominance of the G-lignin-derived phenols comparatively to Slignin-derived phenols, as already observed by $\mathrm{Py}-\mathrm{GC} /$ MS. The relatively high abundance of condensed lignin structures and the slight enrichment in G-lignin units would make the cardoon stalks more difficult to delignify than other herbaceous plants with higher $\mathrm{S} / \mathrm{G}$ ratios and lower amounts of condensed linkages.

\section{Lignin Acylation with Acetates as Seen by DFRC' Analysis}

The HSQC data shown above indicate that the lignin in MCyL is partially acylated at the $\gamma$-position of the side-chain, but cannot provide information on the nature of the acylating group. The DFRC degradation method, which cleaves $\alpha$ and $\beta$-ether linkages in the lignin polymer leaving $\gamma$-esters intact $[36,37]$, seems to be the most appropriate method for the analysis of $\gamma$-acylated lignins. The DFRC degradation method originally developed does not allow the analysis of natively acetylated lignin units because the degradation products are acetylated during the procedure. However, with appropriate modification of the original protocol by replacing acetylating reagents with propionylating ones (so-called DFRC $^{\prime}$ ), it is possible to obtain information about the presence of acetate groups originally acylating the $\gamma-\mathrm{OH}$ in lignin $[26$, $35,38]$. The chromatogram of the $\mathrm{DFRC}^{\prime}$ degradation productsof the MCyL is shown in Fig. 4. The released products are the cis and trans isomers of guaiacyl $(c \mathrm{G}, t \mathrm{G})$ and syringyl $(c \mathrm{~S}, t \mathrm{~S})$ lignin monomers (as their propionylated derivatives) arising from normal $\gamma-\mathrm{OH}$ units in lignin. In addition, the presence of originally $\gamma$-acetylated lignin units $\left(c \mathrm{~S}_{\mathrm{ac}}\right.$ and $t \mathrm{~S}_{\mathrm{ac}}$ ) were also detected in the chromatogram, and confirming that acetylation occurred exclusively at the $\gamma$ carbon of the lignin side-chain, as already observed in the HSQC spectra.The data also indicated that acetylation occurs preferentially over syringyl units (32\% of S-units and only $1 \%$ of G-units are acetylated), as previously noted for most lignins $[35,38,39]$. Sinapyl acetate has been proposed to act as a real lignin monomer participating in lignification [35, $38,40,41]$. The demonstration derived from the $\beta-\beta^{\prime}$ coupling. If the $\gamma$-carbon of a monolignol is pre-acylated, the
Fig. 5 Reconstructed ion chromatogram (sum of the ions at $\mathrm{m} / \mathrm{z} 560,574$, and 588) and structures of the aryltetralin compounds arising from DFRC ${ }^{\prime}$ degradation of lignin $\beta-\beta^{\prime}$ structures containing two (I), one ( $\mathrm{II}_{\mathrm{a}}$ and $\mathrm{II}_{\mathrm{b}}$ ), and none (III) native acetates and present in $\mathrm{MCyL}$

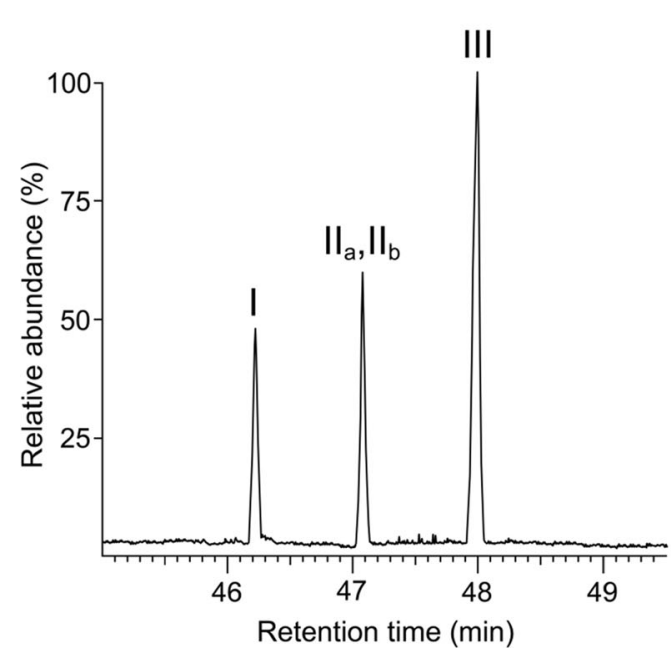

I)<smiles>COCC1Cc2cc(OC)c([N+](=O)[O-])c(O)c2C(c2cc(OC)c(O)c(O)c2O)C1COC</smiles>

$\left.\mathrm{II}_{\mathrm{a}}\right)$<smiles>CCCCOCC1C(COC(C)=O)Cc2cc(OC)c(OCCC)c(OC)c2C1c1cc(OC)c(OCCC)c(OC)c1</smiles>

$\left.\mathrm{II}_{\mathrm{b}}\right)$<smiles>CCCOCC1Cc2cc(OC)c(OCCC)c(OC)c2C(c2cc(OC)c(OCC)c(OC)c2)C1COC(C)=O</smiles>

III)<smiles>CCCOCC1C(COC(C)C)Cc2cc(OC)c(OCCC)c(OC)c2C1c1cc(OC)c(OCCC)c(OC)c1</smiles> 
formation of the normal $\beta-\beta^{\prime}$ resinol structures cannot occur due to the absence of free $\gamma$-hydroxyls needed to re-aromatize the quinone methide moiety. Instead, new tetrahydrofuran structures are formed from the $\beta-\beta^{\prime}$ homo- and crosscoupling of two sinapyl (acylated and non-acylated) monolignols $[35,38,40,41]$. Figure 5 shows the reconstructed chromatograms (sum of the single ion chromatograms of the respective base peaks) $[35,38]$ of the aryltetralin DFRC' degradation products expected from the resinol and tetrahydrofuran dimers arising from the $\beta-\beta^{\prime}$ coupling of the sinapyl monolignols. Interestingly, compounds derived from the DFRC $^{\prime}$ of homo-coupling of sinapyl acetate (I) and crosscoupling of sinapyl acetate and sinapyl alcohol $\left(\mathbf{I}_{\mathbf{a}}\right.$ and $\left.\mathbf{I I}_{\mathbf{b}}\right)$ were clearly observed in the chromatogram of the MCyL, indicating that in cardoon, lignin sinapyl alcohol is preacetylated and behaves as a real monolignol participating in post-coupling reactions, as occurs in other plants.

\section{Conclusions}

The content and structure of cardoon lignin has been studied in detail. For this, the milled cardoon lignin $(\mathrm{MCyL})$ was isolated according to the classical protocol and its structural features studied by different methodologies (Py-GC/MS, NMR, and DFRC'). The lignin was characterized as being slightly enriched in G-units ( $\mathrm{S} / \mathrm{G}$ ratio of $0.7-0.8$ ). The main lignin substructure present includes $\beta-O-4^{\prime}$ alkyl-aryl ethers $(70 \%$ of all interunit linkages), followed by phenylcoumarans (14\%) and minor amounts of resinols (7\%), dibenzodioxocins $(4 \%)$, and spirodienones (5\%). The data indicated that the lignin is partially acylated at the $\gamma-\mathrm{OH}(12 \%$ acylation of all lignin side-chains) with acetate groups that are preferentially attached over syringyl units (32\% of S-units and only $1 \%$ of G-units are acetylated at the $\gamma-\mathrm{OH})$. The occurrence of structures arising from coupling and crosscoupling of sinapyl alcohol and sinapyl acetate confirms that sinapyl acetate acts as a real monolignol involved in lignification reactions in cardoon stalks, as also occurs in other plants. The detailed characterization of the cardoon lignin polymer reported in this study will foster the use of this material in lignocellulosic biorefineries for the production of biofuels and bio-based materials.

Acknowledgments We thank Duarte M. Neiva and Solange Araujo for their contribution during the chemical analysis and Alejandro Rico for his technical support during MCyL isolation. We also thank Dr. Manuel Angulo (CITIUS, University of Seville) for performing the NMR analyses. The research was financed by FEDER through the Operational Program for Competitive Factors of COMPETE, and by the Portuguese Science Foundation (FCT), through a R\&D project PTDC/AGR-FOR/ $3872 / 2012$, and the base funding to the Forest Research Center (CEF) under the PEst-OE/AGR/UI0239/2014 and UID/AGR/00239/2013. This study has also been partially funded by the Spanish project AGL201125379 (co-financed by FEDER funds), the CSIC project 2014-40E-097, and the EU-project INDOX (KBBE-2013-7-613549). The first author was funded by FCT through a post-doctoral grant (SFRH/BPD/95385/ 2013). Jorge Rencoret thanks the CSIC for a JAE-DOC contract of the program "Junta para la Ampliación de Estudios" co-financed by Fondo Social Europeo (FSE).

\section{References}

1. Fernández J, Curt MD, Aguado PL (2006) Industrial applications of Cynara cardunculus L. for energy and other uses. Ind Crop Prod 24:222-229

2. Gominho J, Lourenço A, Palma P, Lourenço ME, Curt MD, Férnandez J, Pereira H (2011) Large scale cultivation of Cynara cardunculus L. for biomass production - a case study. Ind Crop Prod 33:1-6

3. Gominho J, Lourenço A, Curt MD, Férnandez J, Pereira H (2014) Cynara cardunculus in large scale cultivation. A case study in Portugal. Chem Eng Trans 37:529-534

4. Férnandez J, Manzanares P (1989) Cynara cardunculus L., a new crop for oil, paper pulp and energy. Proc. 5th European Conf. Biomass for Energy and Industry, Lisbon, 9-13 October. Elsevier Appl Sci 2:1184-1189, ISBN 1-85166-493-9

5. Pereira H, Gominho J, Miranda I, Pares S (1994) Chemical composition and raw-material quality of Cynara cardunculus L. biomass. In: Hall DO, Grassi G, Sheer H (eds) Biomass for energy and industry. Ponte Press, Bochum, pp 1133-1137

6. Gominho J, Fernández J, Pereira H (2001) Cynara cardunculus L. a new crop for pulp and paper production. Ind Crop Prod 13:1-10

7. Lourenço A, Neiva D, Curt MD, Fernández J, Gominho J, Marques AV, Pereira H (2015) Biomass production of four Cynara cardunculus clones and lignin composition analysis. Biomass Bioenergy 76:86-95

8. Barakat A, Vries H, Rouau X (2013) Dry fractionation process as an important step in current and future lignocellulose biorefineries: a review. BioresourTechnol 134:362-373

9. Stewart D (2008) Lignin as base material for materials applications. Chemistry, applications and economics. Ind Crop Prod 27:202-207

10. Nowakowski DJ, Bridgwater AV, Elliott DC, Meier D, Wild P (2010) Lignin fast pyrolysis: results from an international collaboration. J Anal Appl Pyrolysis 88:53-72

11. Buranov AU, Mazza G (2008) Review. Lignin in straw of herbaceous crops. Ind Crop Prod 28:237-259

12. Björkman A (1956) Studies on finely divided wood. Part I. Extraction of lignin with neutral solvents. Sven Papperstidn 13: 477-485

13. Meier D, Faix O (1992) Pyrolysis-gas-chromatography-mass spectroscopy. In: Lin SY, Dence CW (eds) Methods in lignin chemistry. Springer Series in Wood Science, New York, pp 177-199

14. del Río JC, Gutiérrez A, Hernando M, Landín P, Romero J, Martínez AT (2005) Determining the influence of eucalypt lignin composition in paper pulp yield using Py-GC/MS. J Anal Appl Pyrolysis 74:110-115

15. Lourenço A, Gominho J, Marques AV, Pereira H (2013) Variation of lignin monomeric composition during kraft delignification of Eucalyptus globulus heartwood and sapwood. J Wood Chem Technol 33:1-18

16. Mansfield SD, Kim H, Lu F, Ralph J (2012) Whole plant cell wall characterization using solution-state 2D NMR. Nat Protoc 7(9): 1579-1589

17. Ralph SA, Ralph J, Landucci LL (2004) NMR Database of Lignin and Cell Wall Model Compounds. Available at URL: http://ars. usda.gov/Services/docs.htm?docid=10491 (October 2014) 
18. Faix O, Meier D, Fortman I (1990) Thermal degradation products of wood: a collection of electron impact (EI) mass spectra of monomeric lignin derived products. Holz als Roh-und Werkstoff 48: 351-354

19. Ralph J, Hatfield RD (1991) Pyrolysis-GC-MS characterization of forage materials. J Agric Food Chem 39:1426-1437

20. Bocchini P, Galletti GC, Camarero S, Martínez AT (1997) Absolute quantitation of lignin pyrolysis products using an internal standard. J Chromatogr A 773:227-232

21. Ralph J, Marita JM, Ralph SA, Hatfield RD, Lu F, Ede RM, Peng J, Quideau S, Helm RF, Grabber JHM, Kim H, Jimenez-Monteon G, Zhang Y, Jung HJG, Landucci LL, MacKay JJ, Sederoff RR, Chapple C, Boudet AM (1999) Solution-state NMR of lignin. In: Argyropoulos DS (ed) Advances in lignocellulosics characterization. Tappi Press, Atlanta, pp 55-108

22. del Río JC, Prinsen P, Rencoret J, Nieto L, Jiménez-Barbero J, Ralph J, Martínez AT, Gutiérrez A (2012) Structural characterization of the lignin in the cortex and pith of elephant grass (Pennisetum purpureum) stems. J Agric Food Chem 60:3619-3634

23. del Río JC, Rencoret J, Prinsen P, Martínez AT, Ralph J, Gutiérrez A (2012) Structural characterization of wheat straw lignin as revealed by analytical pyrolysis, 2D-NMR, and reductive cleavage methods. J Agric Food Chem 60:5922-5935

24. Rencoret J, Gutiérrez A, Nieto L, Jimenez-Barbero J, Faulds C, Kim H, Ralph J, Martinez A, del Rio JC (2011) Lignin composition and structure in young versus adult Eucalyptus globulus plants. Plant Physiol 155:667-682

25. Capanema EA, Balakshin MY, Kadla JF (2005) Quantitative characterization of a hardwood milled wood lignin by nuclear magnetic resonance spectroscopy. J Agric Food Chem 53:9639-9649

26. Ralph J, Lu F (1998) The DFRC method for lignin analysis. 6. A simple modification for identifying natural acetates in lignin. $\mathrm{J}$ Agric Food Chem 46:4616-4619

27. Ballesteros M, Negro MJ, Manzanares P, Ballestros I, Sáez F, Oliva JM (2007) Fractionation of Cynara cardunculus (cardoon) biomass by dilute-acid pretreatment. Appl Biochem Biotechnol 136-140: 239-252

28. Villaverde JJ, Ligero P, Vega A (2010) Miscanthus $x$ giganteus as a source of biobased products through organosolv fractionation: a mini review. Open Agric J 4:102-110
29. Ramos PAB, Guerra AR, Guerreiro O, Freire CSR, Silva AMS, Duarte MF, Silvestre AJD (2013) Lipophilic extracts of Cynara cardunculus L.var. altilis (DC): a source of valuable bioactive terpenic compounds. J Agric Food Chem 61:8420-8429

30. Tsutsumi Y, Kondo R, Sakai K, Imamura H (1995) The difference of reactivity between syringyl lignin and guaiacyl lignin in alkaline systems. Holzforschung 49:423-428

31. González-Vila FJ, Almendros G, del Río JC, Martín F, Gutiérrez A, Romero J (1999) Ease of delignification assessment of wood from different Eucalyptus species by pyrolysis (TMAH)-GC/MS and CP/MAS 13C-NMR spectroscopy. J Anal Appl Pyrolysis 49:295305

32. Martínez AT, Rencoret J, Marques G, Gutiérrez A, Ibarra D, Jiménez-Barbero J, del Río JC (2008) Monolignol acylation and lignin structure in some nonwoody plants: a 2D NMR study. Phytochemistry 69:2831-2843

33. Rencoret J, Marques G, Gutiérrez A, Jiménez-Barbero J, Martínez A, del Río JC (2013) Structural modifications of residual lignins from sisal and flax pulps during soda-AQ pulping and TCF/ECF bleaching. J Agric Food Chem 52:4695-4703

34. Villaverde JJ, Li J, Ek M, Ligero P, Vega A (2009) Native lignin structure of Miscanthus $x$ giganteus and its changes during acetic and formic acid fractionation. J Agric Food Chem 57:6262-6270

35. del Río JC, Rencoret J, Marques G, Gutiérrez A, Ibarra D, Santos JI, Jiménez-Barbero J, Martínez AT (2008) Highly acylated (acetylated and/or $p$-coumaroylated) native lignins from diverse herbaceous plants. J Agric Food Chem 56:9525-9534

36. Lu F, Ralph J (1997) The DFRC method for lignin analysis. Part 1. A new method for $\beta$-aryl ether cleavage: lignin model studies. J Agric Food Chem 45:4655-4660

37. Lu F, Ralph J (1998) The DFRC method for lignin analysis. 2. Monomers from isolated lignin. J Agric Food Chem 46:547-552

38. del Río JC, Marques G, Rencoret J, Martínez AT, Gutiérrez A (2007) Occurrence of naturally acetylated lignin units. J Agric Food Chem 55:5461-5468

39. Ralph J (1996) An unusual lignin from kenaf. J Nat Prod 59:341342

40. Lu F, Ralph J (2002) Preliminary evidence for sinapyl acetate as a lignin monomer in kenaf. Chem Commun 1:90-91

41. Lu F, Ralph J (2005) Novel $\beta-\beta$ structures in lignins incorporating acylated monolignols. Appita 233-237 